\title{
Effects of Supplemental Boron on Intestinal Proliferation and Apoptosis in African Ostrich Chicks
}

\author{
Efectos del Boro Suplementario sobre la Proliferación Intestinal \\ y Apoptosis en Polluelos de Avestruz Africana
}

PengPeng Sun"; You Luo*; Xin Tong Wu*; Abdur Rahman Ansari*; Jing Wang*; KeLi Yang*; Ke Xiao* \& KeMei Peng*

SUN, P.; LUO, Y.; WU, X. T.; ANSARI, A. R.; WANG, J; YANG, K.; XIAO, K. \& PENG, K. Effects of supplemental boron on intestinal proliferation and apoptosis in African ostrich chicks. Int. J. Morphol., 34(3):830-835, 2016, 2016.

SUMMARY: Boron is an essential trace element which plays an important role in process of metabolism and the function of the tissues. However, the effects of boron on the intestinal cells in African ostrich chicks are poorly reported. Therefore, this study was designed to investigate the role of boron on proliferation and apoptosis of the intestinal cells. A total of 36, ten day-old ostrich chicks were randomly divided into six groups and fed on the same basal diet supplemented with $0,40,80,160,320$ and $640 \mathrm{mg} / \mathrm{L}$ boric acid in drinking water for 80 days. Proliferating cell nuclear antigen (PCNA) was used to test the proliferation index of intestine in different group by immunohistochemical staining (IHC). Apoptotic cells of intestine were detected by Dutp-biotin nick end labeling (TUNEL) reaction and evaluated by integral optical density (IOD). Results showed that proliferation of intestinal cells significantly increased in groups of 80, 160, 320 and $640 \mathrm{mg} / \mathrm{L}$. TUNEL reaction showed that apoptosis significantly decreased in $80 \mathrm{mg} / \mathrm{L}$ groups, while significantly increased in high dose of boron groups (320 and $640 \mathrm{mg} / \mathrm{L}$ ), especially in epithelium. In conclusion, low dose of boron-supplemented water could promote cell proliferation and depress apoptosis, while high dose of boron could cause intestinal apoptosis and thus we found increased proliferation of intestine cell as a compensatory adaption. These findings may support optimal dosage of boron that could protect the development of ostrich intestine, while high dosage of boron could suppress it, or even has toxic effects on it.

KEY WORDS: Apoptosis; Boron; Intestine; Ostrich chicks; Proliferation.

\section{INTRODUCTION}

Boron, a kind of active bio-trace-element, has been suggested to be an essential nutrient for animals and human beings (Nielsen, 1997). Boron plays an important role in the activity of many metabolic enzymes, as well as in the metabolism of steroid hormones and several micronutrients, including calcium, magnesium, and vitamin D (Devirian \& Volpe, 2003). It is reported that boron supplementation of a semipurified diet for weanling pigs could improve feed efficiency and bone strength characteristics (Armstrong et al., 2000). The optimal dose of boron can promote the development of the intestinal organizational structure, thus enhances the gastrointestinal absorption ability (Wang et al., 2007). To our knowledge, the mechanism of boron that might affect on intestinal function is poorly described in scientific published reports.

The intestinal luminal surface is covered by epithelial cells as a consequent it is in direct contact with various kinds of antigens and toxins in food. Therefore, the intestinal epithelium is a highly dynamic tissue, characterized by a remarkable turnover rate and complete renewal of the entire cell population every 72 to 96 hours (Leblond, 1981). Intestinal mucosal homeostasis is responsible for the prime condition of gut health and it also depends on a balance between cell proliferation and cell death (Wolf et al., 1999). It is well known that the stem cells of crypts continually differentiate into epithelial cells to supply or repair aged and apoptotic cells in small intestinal villus (Clevers, 2013). Apoptosis is programmed cell death, by which senescent or otherwise dysfunctional cells are removed. Apoptosis participates in renewing and repairing process in the small intestinal mucosal cells. It is only possible by balancing both the processes of proliferation and apoptosis that can maintain mucosal integrity and ensure its normal function (Ruemmele \& Seidman, 1998). 
Proliferating cell nuclear antigen (PCNA) is a kind of nucleus peptide that only synthesized or expressed in the cell proliferation. It is obviously expressed in late G1 phase and significantly increased in S phase. Therefore, PCNA was used as a marker of cell proliferation for organ development and tumor research (Dietrich, 1993). Our prior studies have also showed $80 \mathrm{mg} / \mathrm{L}$ boron significantly promoted the development of ostrich intestine, including villus height and villus height/crypt ratio, which indicate boron may affect intestinal cell proliferation and apoptosis. According to our knowledge, until now no scientific study has described the effects of boron on intestinal developmental mechanism in African ostrich chicks. Therefore, our research aims to determine the optimal dose of boron for the development of ostrich intestine by detecting cell apoptosis and proliferation, as well as provides a basic theory for the physiological function of boron.

\section{MATERIAL AND METHOD}

Chickens, Diets and Collection of Tissues. Thirty-six, 10 day-old healthy ostrich chicks were randomly divided into six groups ( $n=6$ in each group), and supplemented with boron in drinking water (drinking water from the tap, the boron content was $0.11 \mathrm{mg} / \mathrm{g}$, negligible) at the concentrations of 0 (control group), 40, 80, 160, 320, and $640 \mathrm{mg} / \mathrm{L}$, respectively, until the birds were 90 days old and were fed with a blend of custom-made premix diet.

After ostriches were euthanized, intestine (jejunum) were immediately removed and fixed in $4 \%$ paraformaldehyde. After $24 \mathrm{~h}$ of fixation, samples were dehydrated in a graded series of ethanol, cleared by xylene, and embedded in paraffin. Samples were then sectioned (about $5 \mathrm{~mm}$ in thickness) and air dried onto glass slides overnight.

All experimental procedures involving animals were approved by the Huazhong Agricultural University Animal Care and Use Committee.

Immunohistochemistry. The primary antibodies rabbit antiPCNA antibody (Wuhan Elabscience Biotechnology Co., Ltd., China) was used to detect proliferation in intestinal tissue. All procedures were strictly performed in accordance with the manufacturer`s directions. Paraffin sections were dewaxed by xylene, hydrated with gradient alcohol, inactivated endogenous enzymes with $3 \% \mathrm{H}_{2} \mathrm{O}_{2}$ for $10 \mathrm{~min}$, repaired antigen in a microwave oven, blocked non-specific binding sites with $5 \%$ goat serum for $30 \mathrm{~min}$, and then probed with primary PCNA antibody (diluted 1:200 in PBS) for overnight, biotin-conjugated secondary antibody $(1: 100)$ for $30 \mathrm{~min}$ at $37^{\circ} \mathrm{C}$, and color development by SABC $(1: 100)$ under microscope. Covered with waterborne mount and finally detected directly under a light microscope. Negative control slides added $0.1 \mathrm{~mol} / \mathrm{L}$ PBS instead of primary antibody, so these have no immunological reaction. The stained sections were evaluated under a light microscope (BX51; Olympus, Tokyo, Japan) with a digital camera (DP72; Olympus, Tokyo, Japan).

TUNEL. Terminal deoxynucleotidyl transference-mediated biotinylated deoxyuridine triphosphate nick end labeling technique (TUNEL) was adopted to detect intestinal villus apoptosis according to the protocol of TUNEL Detection System (Wuhan Boster Biochemical Techniques Co. Ltd., China). Nucleus stained by yellow color were considered as positive cells under a microscope. Slices treated without TdT were the negative control ones. All positive signals were evaluated by light microscopic examination (BX51; Olympus, Tokyo, Japan) under a 200x magnification.

Statistical Analysis. Statistical analysis was performed using the Statistical Package for the Social Sciences (SPSS, v.17.0; SPSS, Chicago, IL, USA) and GraphPad Prism 5 software (GraphPad, San Diego, CA, USA). Integral optical density (IOD) of the TUNEL was measured by Image-Pro Plus software (IPP, v.4.5.1; Media Cybernetics, Silver Springs, MD, USA). In the perspective of control magnification, five sections were randomly selected to count numbers of PCNApositive cells and IOD of the TUNEL data. Cell proliferation index $=$ PCNA positive cell numbers $/ 100$ cells $\times 100 \%$. One-way analysis of variance (ANOVA) was performed to assess the significance of differences. $P$ values $\leq 0.05$ were considered significantly different.

\section{RESULTS}

Expression of PCNA in the Ostrich chick intestine in different groups. The PCNA positive cells stained yellow that were mainly scattered in the nucleus of intestinal crypt cells (intestinal glands) whereas only a few were present in lamina propria of intestinal villus. The number of positive cells of PCNA increased significantly ( $\mathrm{p}<0.01$ ) in $80,160,320$ and $640 \mathrm{mg} / \mathrm{L}$ group, compared with control group (Fig. 1).

Apoptosis. Apoptotic cells were mainly distributed in the lamina propria of the intestinal villus in control, 40, 80 and $160 \mathrm{mg} / \mathrm{L}$ groups and their number significantly $(\mathrm{p}<0.01)$ decreased in $80 \mathrm{mg} / \mathrm{L}$ group compared with control group. In 320 and $640 \mathrm{mg} / \mathrm{L}$ groups, apoptotic cells were not only distributed in the lamina propria, but also found in intestinal 

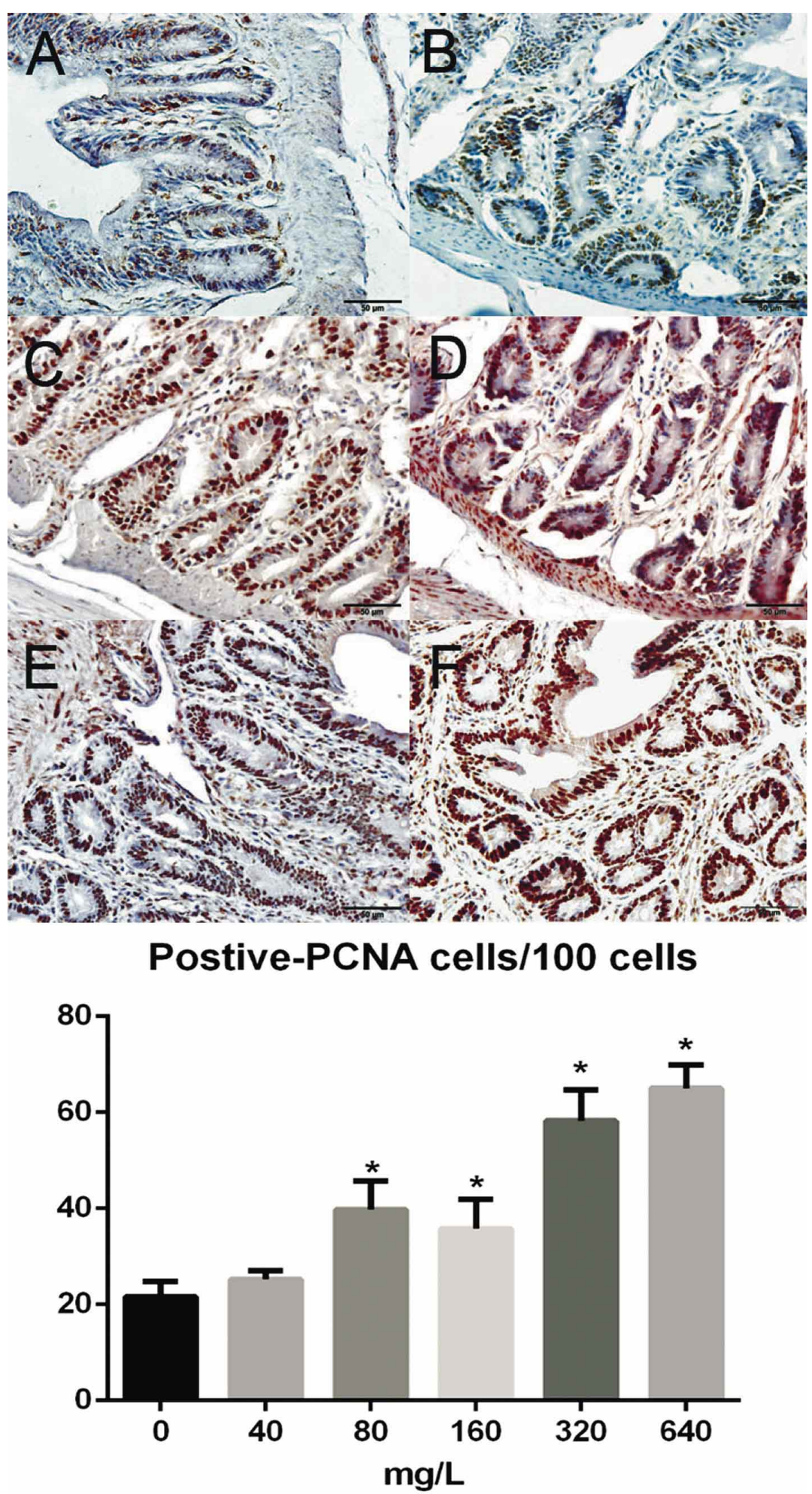

Fig. 1. Distribution patterns of PCNA-positive cells (IHC) and cell proliferation index in the intestine (jejunum) of 90 days old ostriches. The brown cell nucleus are PCNApositive signal. Control group (A); $40 \mathrm{mg} / \mathrm{L}$ group (B); $80 \mathrm{mg} / \mathrm{L}$ group (C); $160 \mathrm{mg} / \mathrm{L}$ group (D); $320 \mathrm{mg} / \mathrm{L}$ group (E) and $640 \mathrm{mg} / \mathrm{L}$ group $(\mathrm{F}) . *(\mathrm{p}<0.01)$. epithelial cells. The IOD of TUNELpositive cells also showed differences among the six experimental groups by IPP analysis. Compared to control group, the IOD of TUNEL-positive cells showed significantly $(\mathrm{P}<0.01)$ decreased in $80 \mathrm{mg} /$ L group, while significantly $(\mathrm{P}<0.01)$ increased in 320 and $640 \mathrm{mg} / \mathrm{L}$ groups (Fig. 2).

\section{DISCUSSION}

For the ostrich farming, the mortality rate of ostrich chicks in the first three months can reach $50 \%$ and digestive tract disease is one of the main reasons (Samson, 1997). Intestine, as the largest digestive and immune organ, not only absorbs the nutrients, but also prevents the invasion of pathogens and antigens. Past studies showed that the destruction of the intestinal mucosal barrier function can lead to intestinal bacteria and toxins shift to the systemic circulation, resulting in a large number of inflammatory mediators and cytokines release that might produce harmful substances such as oxygen free radicals, which eventually cause organs dysfunction (Beattie \& Siriwardena, 2000). So the integrity of the intestinal morphology is compromised along with its normal function. Normally intestinal mucosal cells are in constantly selfrenewing process and the cell apoptosis involved in small intestinal mucosal cells repair mechanism, which keep the balance between proliferation and apoptosis, so as to maintain mucosal integrity (Chen et al., 2012).

Cell apoptosis is one of the forms of cell death and can eliminate the injured, aged and mutant cells, which maintains tissue balance. It not only exists in ordinary life processes, such as growth and development, but also widely involved in the pathogenesis of many diseases (Trieb et al., 1997). Boron is a kind of trace elements with many biological activities and mainly absorbed by the gastrointestinal tract, damaged skin and 


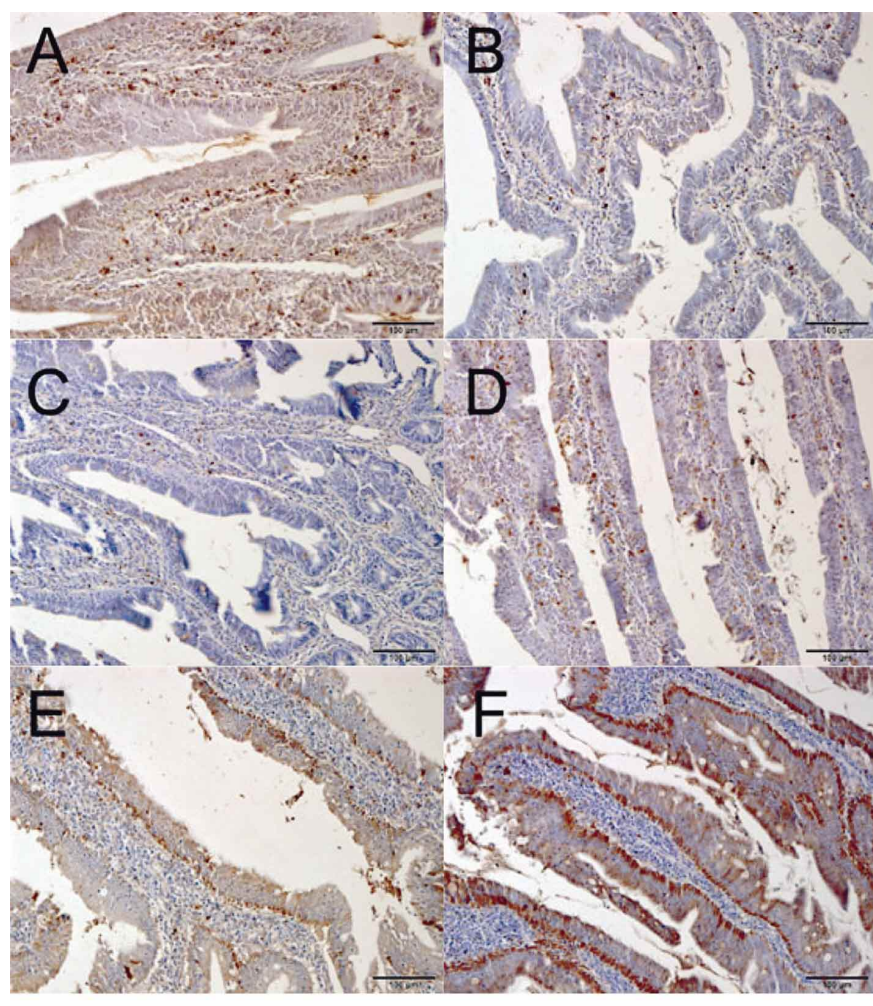

90d-TUNEL

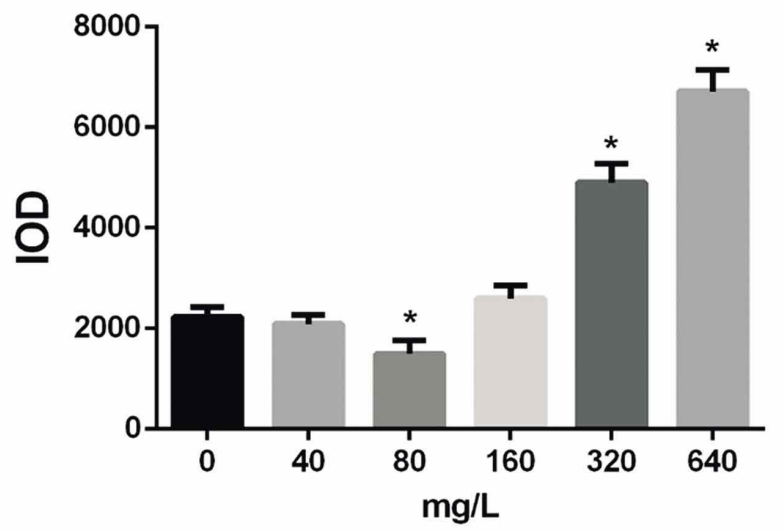

Fig. 2. Effects of boron on apoptosis in 90 days old ostrich intestine (jejunum, TUNEL). The brown cells are apoptotic cells. Control group (A); $40 \mathrm{mg} / \mathrm{L}$ group (B); $80 \mathrm{mg} / \mathrm{L}$ group (C); $160 \mathrm{mg} / \mathrm{L}$ group (D); 320 $\mathrm{mg} / \mathrm{L}$ group $(\mathrm{E})$ and $640 \mathrm{mg} / \mathrm{L}$ group $(\mathrm{F}) . *(\mathrm{p}<0.01)$.

respiratory tract. Past researches have shown that low dose of boron can inhibit the apoptosis of tibia and thymus cells, while high dose of boron had opposite effects (Cheng et al., 2011; Xiao et al., 2015). In our research, we found similar results with those studies. It's worth noting that the apoptotic cells are mainly distributed in intestinal epithelial cells in 320 and $640 \mathrm{mg} / \mathrm{L}$ group, which indicates that high dose of boron caused destruction of the intestinal mucosal barrier function. Two reasons may be responsible for the cells apoptosis of boron. Firstly, boron may affect the antioxidant function of cells. Appropriate amount of boron could decrease lipid peroxidation by enhancing the antioxidant enzyme activity and improve free radical clearance ability (Hu et al., 2014). Secondly, boron may affect caspase-3 gene expression in mitochondrial pathway. Because caspase-3 plays a crucial role in the mitochondrial apoptosis pathway and low dose of boron inhibits caspase-3 expression, while high dose of boron promoted the expression of caspase3 (Lakhani et al., 2006; Tang et al., 2015).

Intestinal mucosal epithelial cells keep constantly updated for whole life, which is accomplished by proliferation and differentiation of intestinal epithelium stem cells located in the intestinal mucosa crypts to replace dead or apoptotic somatic cells. The expression of PCNA represents the strength of cell proliferation and reflect the intestinal mucosal cells proliferation and cell hyperplasia. Previous studies documented role of boron in animal growth and development (Eckhert, 1998; Wang et al., 2014) suggesting a possible function for boron in cell growth and proliferation. Park et al. (2005) reported that relatively low concentration borate was strongly mitogenic, whereas at high concentrations it was toxic. In present study, cell proliferation index showed significant increase in 80,160, 320 and $640 \mathrm{mg} / \mathrm{L}$ groups, which suggests that boron has activated the immature stem cells in basal crypt compartment with a high mitotic activity. However, high dose of boron (320 and $640 \mathrm{mg} / \mathrm{L}$ ) caused cell proliferation may have other reasons. It is also reported that exaggerated or accelerated cell dying via apoptosis results in a paucity of mature enterocytes leading to villus atrophy and epithelial destruction (Ruemmele et al., 2002). Therefore, immature stem cells continually proceed for mitosis to compensate the absorption function as large number of intestinal epithelial cells died by apoptosis, which had been proved a kind of compensatory adaptation for wound healing (Williamson, 1978). Researchers in our lab have also found that lowsupplemental boron could promote intestinal mucosal immunity that gives more protection to intestinal epithelium. This may be related to the intestinal cells proliferation and apoptosis, but it needs more studies to further investigate the underlying mechanism involved.

Above all, optimal dose of supplemental boron, especially $80 \mathrm{mg} / \mathrm{L}$, could promote cell proliferation and inhibit apoptosis. However, high dose of boron not only increased cell apoptosis, but also promoted intestinal cell proliferation to act as compensatory adaptation. 
ACKNOWLEDGEMENTS . This study was approved and financially supported by the National Natural Science Foundation Project of China (No. 31272517). There is no conflict of interest in this study.

SUN, P.; LUO, Y.; ANSARI, A. R.; WANG, J; YANG, K.; XIAO, K. \& PENG, K. Efectos de boro suplementario sobre la proliferación intestinal y apoptosis en polluelos de avestruz africana. Int. J. Morphol., 34(3):830-835, 2016.

RESUMEN: El boro es un elemento esencial que desempeña un importante rol en el proceso del metabolismo y en la función de los tejidos. Sin embargo, existe poca información de los efectos del boro en las células intestinales de polluelos de avestruz Africana. Por lo tanto, este estudio fue diseñado para investigar el papel del boro sobre la proliferación y la apoptosis de las células intestinales. Un total de 36 polluelos de avestruz de diez días se dividieron, aleatoriamente, en seis grupos y se alimentaron con una misma dieta basal suplementada con $0,40,80,160,320$ y 640 $\mathrm{mg} / \mathrm{L}$ de ácido bórico en agua potable durante 80 días. Se utilizó el antígeno nuclear celular de células en proliferación (PCNA) para probar el índice de proliferación de intestino en diferentes grupos por tinción inmunohistoquímica. Las células apoptóticas del intestino fueron detectadas por dUTP-biotina nick etiquetado para reacción (TUNEL) y evaluadas por la densidad óptica integrada (DOI). Los resultados mostraron que la proliferación de las células intestinales aumentó significativamente en los grupos de 80 , 160, 320 y 640 mg /L. La reacción TUNEL mostró que la apoptosis se redujo significativamente en los grupos de $80 \mathrm{mg} / \mathrm{L}$, mientras que el aumento fue significativo en grupos tratados con dosis alta de boro (320 y $640 \mathrm{mg} / \mathrm{L}$ ), especialmente en el epitelio. En conclusión, la baja dosis de boro en agua suplementada podría promover la proliferación celular y deprimir la apoptosis, mientras que altas dosis de boro podrían provocar apoptosis intestinal y, por lo tanto, se halló una mayor proliferación de las células del intestino como una adaptación compensatoria. Estos hallazgos indican que una dosis óptima de boro podría proteger el desarrollo del intestino del avestruz, mientras que altas dosis de boro podrían suprimirla, o incluso tener efectos tóxicos sobre ella.

PALABRAS CLAVE: Apoptosis; Boro; Intestino; Polluelos de avestruz; Proliferación.

\section{REFERENCES}

Armstrong, T. A.; Spears, J. W.; Crenshaw, T. D. \& Nielsen, F. H. Boron supplementation of a semipurified diet for weanling pigs improves feed efficiency and bone strength characteristics and alters plasma lipid metabolites. J. Nutr., 130(10):2575-81, 2000.

Beattie, G. \& Siriwardena, A. Bacterial infection and extent of necrosis are determinants of organ failure in patients with acute necrotizing pancreatitis. Br. J. Surg., 87(2):250, 2000.
Chen, X.; Zhao, H. X.; Fu, X. S.; Li, C. P. \& Zhong, X. L. Glucagonlike peptide 2 protects intestinal barrier in severe acute pancreatitis through regulating intestinal epithelial cell proliferation and apoptosis. Pancreas, 41(7):1080-5, 2012.

Cheng, J.; Peng, K.; Jin, E.; Zhang, Y.; Liu, Y.; Zhang, N.; Song, H.; Liu, H. \& Tang, Z. Effect of additional boron on tibias of African ostrich chicks. Biol. Trace Elem. Res., 144(1-3):53849, 2011.

Clevers, H. The intestinal crypt, a prototype stem cell compartment. Cell, 154(2):274-84, 2013.

Devirian, T. A. \& Volpe, S. L. The physiological effects of dietary boron. Crit. Rev. Food Sci. Nutr., 43(2):219-31, 2003.

Dietrich, D. R. Toxicological and pathological applications of proliferating cell nuclear antigen (PCNA), a novel endogenous marker for cell proliferation. Crit. Rev. Toxicol., 23(1):77-109, 1993

Eckhert, C. D. Boron stimulates embryonic trout growth. J. Nutr., 128(12):2488-93, 1998.

Hu, Q.; Li, S.; Qiao, E.; Tang, Z.; Jin, E.; Jin, G. \& Gu, Y. Effects of boron on structure and antioxidative activities of spleen in rats. Biol. Trace Elem. Res., 158(1):73-80, 2014.

Lakhani, S. A.; Masud, A.; Kuida, K.; Porter, G. A. Jr.; Booth, C. J.; Mehal, W. Z.; Inayat, I. \& Flavell, R. A. Caspases 3 and 7: key mediators of mitochondrial events of apoptosis. Science, 311(5762):847-51, 2006.

Leblond, C. P. The life history of cells in renewing systems. Am. J. Anat., 160(2):114-58, 1981.

Nielsen, F. H. Boron in human and animal nutrition. Plant Soil, 193(1-2):199-208, 1997.

Park, M.; Li, Q.; Shcheynikov, N.; Muallem, S. \& Zeng, W. Borate transport and cell growth and proliferation. Not only in plants. Cell Cycle, 4(1):24-6, 2005.

Ruemmele, F. M. \& Seidman, E. G. Cytokine--intestinal epithelial cell interactions: implications for immune mediated bowel disorders. Zhonghua Min Guo Xiao Er Ke Yi Xие Hui Za Zhi, 39(1):1-8, 1998.

Ruemmele, F. M.; Seidman, E. G. \& Lentze, M. J. Regulation of intestinal epithelial cell apoptosis and the pathogenesis of inflammatory bowel disorders. J. Pediatr. Gastroenterol. Nutr., 34(3):254-60, 2002.

Samson, J. Prevalent diseases of ostrich chicks farmed in Canada. Can. Vet. J., 38(7):425-8, 1997.

Tang, J.; Zheng, X. T.; Xiao, K.; Wang, K. L.; Wang, J.; Wang, Y. X.; Wang, K.; Wang, W.; Lu, S.; Yang, K. L.; Sun, P. P.; Khaliq, H.; Zhong, J. \& Peng, K. M. Effect of Boric Acid 
SUN, P.; LUO, Y.; WU, X. T.; ANSARI, A. R.; WANG, J; YANG, K.; XIAO, K. \& PENG, K. Effects of supplemental boron on intestinal proliferation and apoptosis in African ostrich chicks. Int. J. Morphol., 34(3):830-835, 2016, 2016.

Supplementation on the Expression of BDNF in African Ostrich Chick Brain. Biol. Trace Elem. Res., 170(1):208-15, 2016.

Trieb, K.; Eberl, T.; Steger, M.; Ofner, D.; Steinlechner, R.; Gnaiger, E.; Schröcksnadel, H.; Grubeck-Loebenstein, B. \& Margreiter, R. Apoptosis is involved in endothelial cell damage during preservation and influenced by organ storage solutions. Transplant. Proc., 29(1-2):416-8, 1997.

Wang, J.; Li, S. H.; Jin, G. M.; Shang, C. F.; Chen, H. L. \& Gu, Y. F. Effect of drinking-boron on jejunum development of animal. Stud. Trace Elem. Health, 24(2):1-4, 2007.

Wang, W.; Xiao, K.; Zheng, X.; Zhu, D.; Yang, Z.; Tang, J.; Sun, P.; Wang, J. \& Peng, K. Effects of supplemental boron on growth performance and meat quality in African ostrich chicks. J. Agric. Food Chem., 62(46):11024-9, 2014.

Williamson, R. C. Intestinal adaptation (first of two parts). Structural, functional and cytokinetic changes. N. Engl. J. Med., 298(25):1393-402, 1978.

Wolf, S. E.; Ikeda, H.; Matin, S.; Debroy, M. A.; Rajaraman, S.; Herndon, D. \& Thompson, J. C. Cutaneous burn increases apoptosis in the gut epithelium of mice. J. Am. Coll. Surg., 188(1):10-6, 1999.

Xiao, K.; Ansari, A. R.; Rehman, Z. U.; Khaliq, H.; Song, H.; Tang, J.; Wang. J.; Wang. W.; Sun. P. P.; Zhong, J. \& Peng, K. M. Effect of boric acid supplementation of ostrich water on the expression of Foxn1 in thymus. Histol. Histopathol., 30(11):1367-78, 2015.

\section{Correspondence to: \\ Kemei Peng \\ College of Veterinary Medicine \\ Huazhong Agricultural University \\ Wuhan 430070 \\ CHINA}

Email: kemeip@163.com

Received: 09-01-2016

Accepted: 05-05-2016 